\title{
Teaching Music in English: A Content- Based Instruction Model in Secondary Education
}

Enseñando música en inglés: un modelo de enseñanza basada en

contenidos en educación secundaria obligatoria

Ensinar música em inglês: um modelo de ensino baseado em conteúdo na educação secundária obrigatória

Lucía BELLÉS-CALVERA

http://orcid.org/0000-0002-1329-6395. PhD student. Universitat Jaume I, Spain. lucia.belles@uji.es

Received: 2018-03-06

Accepted by peers: 2018-07-06
Sent for peer review: 2018-05-15

Approved: 2018-07-27

To reference this article in APA style / Para citar este artículo en APA / Para citar este artigo Bellés-Calvera, L. (2018). Teaching music in English: A content-based instruction model in secondary education. LACLIL, 11(1), 109-139. DOI: 10.5294/laclil.2018.11.1.6 
ABSTRACT. Over the past few years, there has been a growing interest in the teaching and learning of several languages in an attempt to generate multilingual education opportunities, particularly in Europe. In response to the demands of our globalized society, Content-Based Instruction (CBI), which has also been referred to as "immersion and Content and Language Integrated Learning (CLIL) programs," emerged as a teaching approach that combines the learning of curricular contents and the communicative competence in the target language. This study was carried out at a public high school set in a Spanish bilingual community, where music is taught through a CLIL approach in English class. The purpose of this paper is to examine how students value their music lessons in English and to check the adequacy of teaching music as a subject in English. To achieve this goal, materials adapted to their level of proficiency and a final questionnaire were designed. Results indicate that students are satisfied with this proposal, since they consider these music lessons to be easier than the regular ones. Not only did they enjoy being exposed to English in these music lessons, but a considerable number of students would also like to take a CLIL program in the near future. Pedagogical implications to this CBI model account for the development of learners' autonomy, the use of audio-visual aids and further research in bilingual and multilingual regions overseas.

Keywords: Instructional programs; educational policies; secondary education; music; foreign language instruction.

RESUMEN. En los últimos años, ha habido un gran interés en la enseñanza y el aprendizaje de lenguas con el propósito de crear nuevas oportunidades en lo que concierne a la educación multilingüe. En respuesta a las demandas de nuestra sociedad, la enseñanza basada en contenidos, también conocida como "Aprendizaje Integrado de Contenidos y Lenguas Extranjeras" (AICLE), surgió como un enfoque que permite a los estudiantes aprender los contenidos de una asignatura en una lengua extranjera. Este artículo presenta un estudio llevado a cabo en un centro público de educación secundaria obligatoria, situado en una comunidad autónoma bilingüe de España, en el cual se enseña una unidad didáctica de música utilizando dicho enfoque en la asignatura de Inglés. El objetivo es determinar cómo valoran los estudiantes sus clases de música en inglés y comprobar la idoneidad de que una asignatura como música sea impartida en inglés. Para alcanzar este objetivo, se diseñaron una serie de materiales y cuestionarios adaptados a su dominio de la lengua meta. Los resultados sugieren que los alumnos están satisfechos con esta propuesta, pues consideran que estas clases de música son más fáciles. Los estudiantes no solo estuvieron expuestos al inglés en sus clases de música, sino que a un número considerable de estudiantes les gustaría cursar un programa AICLE en un futuro. Las implicaciones pedagógicas de este modelo de enseñanza basado en contenidos se centran en el desarrollo de la autonomía de los estudiantes, el uso de herramientas audiovisuales y la investigación en regiones bilingües y multilingües.

Palabras clave: programas de enseñanza; política educativa; educación secundaria obligatoria; música; enseñanza de una lengua extranjera.

RESUMO. Nos últimos anos tem havido um grande interesse no ensino e aprendizagem de línguas com o objetivo de criar novas oportunidades em termos de educação multilíngue. Em resposta às demandas de nossa sociedade, o ensino baseado em conteúdo, também conhecido como "Conteúdo Integrado e Aprendizagem de Línguas Estrangeiras" (CLIL), surgiu como uma abordagem que permite aos alunos aprender o conteúdo de uma disciplina em uma língua estrangeira. Este artigo apresenta um estudo realizado em um centro público de ensino médio obrigatório, localizado em uma comunidade autônoma bilíngue da Espanha, na qual uma unidade didática de música é ensinada usando essa abordagem na aula de inglês. O objetivo é determinar como os alunos valorizam suas aulas de música em inglês e verificar a adequação de um assunto à medida que a música é ensinada em inglês. Para atingir este objetivo, uma série de materiais e questionários adaptados ao seu domínio da língua-alvo foram projetados. Os resultados sugerem que os alunos estão satisfeitos com essa proposta, pois consideram que essas lições de música são mais fáceis. Os alunos não só foram expostos ao inglês em suas aulas de música, mas um número considerável de alunos gostaria de participar de um programa da CLIL no futuro. As implicações pedagógicas desse modelo de ensino baseado em conteúdo estão focadas no desenvolvimento da autonomia do aluno, no uso de ferramentas audiovisuais e na pesquisa em regiões bilíngues e multilíngues.

Palavras-chave: programas de ensino; política educacional; ensino secundário obrigatório; música; ensino de uma língua estrangeira. 


\section{Introduction}

Nowadays, educators find themselves in classrooms where their students have different and diverse linguistic and cultural backgrounds. In other words, learners speak languages other than the first language of the country they live in. In the last decades, the European Union has promoted a new linguistic policy aimed at supporting multilingual classrooms in an attempt to generate a new learning environment in which linguistic diversity is valued (European Commission, 2015). Therefore, language learners have the opportunity to broaden their minds and show respect for others.

In multilingual education, Content-Based Instruction (CBI) has been found to be an effective approach to foreign language teaching. So far, CBI has been usually confused with concepts such as French immersion programs in Canada and Content and Language Integrated Learning (CLIL) immersion programs in Europe (Cenoz, 2015). According to Stoller (2008), CBI is an umbrella term used to describe all the approaches in which language and content are combined. Following this definition, not only do students have the opportunity to acquire new meaningful knowledge related to subject areas like mathematics or science (Heo, 2006), but they can also improve their skills in the target language. Nonetheless, the implementation of CBI programs may vary depending on the educational level-preschool, primary education, secondary education, and higher education - as well as on the teaching curriculum (Genesee \& Lindholm-Leary, 2013).

Until now, research on CBI has dealt mainly with students' use of language. It has been observed that those students enrolled in CBI programs are more proficient in the target language than those who receive instruction through monolingual programs (Fortune, 2001; Lyster, 2007). Other CBI concerns are linked to CLIL issues, given that there seems to be some inconsistency in the results obtained in these studies (Dalton-Puffer, 2007; Lasagabaster, 2008; Marsh, Hau, \& Kong, 2000; Yip, Tsang, \& Cheung, 2003). While some scholars point out the positive effect of CLIL programs when it comes to language learning (Dalton-Puffer, 2007; Lasagabaster, 2008), others argue that they have a detrimental effect on the learning of subject-specific contents (Marsh, 
Hau, \& Kong, 2000; Yip, Tsang, \& Cheung, 2003). That being said, both the potential benefits as well as the drawbacks found in CLIL programs, which can be found within the CBI approach, should be examined.

\section{Advantages and Disadvantages in CLIL Programs}

Previous research has shown the positive effects of CLIL instruction (Wolff, 2002; Genesee, 2006; Nold, Hartig, Hinz, \& Rossa, 2008; Köller, Leucht, \& Pant, 2012). Ruiz de Zarobe, Sierra, and Gallardo (2011) indicate that it raises learners' linguistic competence and confidence as they develop their receptive skills (e.g., reading and listening) and become fluent in speaking and writing, the latter being characterized by complex utterances in terms of lexical items and syntax. By being exposed to authentic input on a regular basis, other areas such as vocabulary and morphology (e.g., verbal tenses and morphemes) are favored by this approach. What is more, the CLIL approach seems to have a positive impact on students' learning process, since it works in a wide range of educational areas (Wolff, 2002). More specifically, Physical Education class involves activities where oral communication is reinforced by the use of expressive components and body language (García, García, \& Yuste, 2012). These elements will allow students to understand explanations easily regardless of their proficiency level. Hence, students' and teachers' interactions occur as part of a game, thereby fostering incidental learning (García, García, \& Yuste, 2012).

Despite all the positive effects mentioned above, some drawbacks of the CLIL approach may be considered. A possible barrier has to do with the teachers' workload, due to the lack of available materials to teach CLIL in the market. Likewise, some studies have reported that pronunciation (Gallardo, Gómez-Lacabex, \& García-Lecumberri, 2009), syntax, and accuracy (Ruiz de Zarobe, Sierra, \& Gallardo, 2011) are affected negatively in CLIL settings. Another weakness found in CLIL instruction has to do with assessment. Specialist teachers consider that the content knowledge students are expected to learn in a given subject is more important than linguistic issues, whereas language teachers tend to analyze language accuracy. As a consequence, some content 
teachers do not provide students with language corrective feedback, since the focus is on meaning rather than on form (Lasagabaster \& Ruiz de Zarobe, 2010). This practice may lead to fossilization, which is the internalization of incorrect linguistic forms.

To overcome the challenges that CLIL and CBI programs face, teacher training courses as well as team teaching should be promoted. In this respect, teachers should not only be given instruction in terms of assessment, but they could also share their own experiences and learn from their colleagues (Pavón \& Ellison, 2013). These practices would promote cooperation between content and language teachers, which may help design attractive lesson plans and materials (Ioannou-Georgiou, 2012).

\section{Linguistic Policies in the European Educational Context}

As a point of departure, CLIL has become widely popular in the last years in Europe. The main objective of the European Union is to promote the learning of at least two languages other than the citizens' mother tongues. The attempts at all levels to guarantee language diversity have not only had an impact on the progress of language teaching in Europe, but they have also influenced the educational systems in different countries. Over the years, CLIL has been implemented at different education levels, ranging from primary to secondary and university levels in order to prepare competent citizens that can cope with all kinds of situations, either in their personal or professional interactions (Jäppinen, 2006).

The implementation of CLIL programs is unique, as it may be applied differently in every country. Within the European Union, the Bologna Declaration (1999) states that a language level certification is required at the end of the degrees offered in higher education institutions. To do so, most Spanish universities have opted to offer some of their degree modules as well as some postgraduate courses in English. That is, a CLIL model is applied to university levels so that students will familiarize themselves with vocabulary and content that allows them to communicate effectively in their professional lives. Clear examples may be found at the universities of Granada and Jaume I (Castellón). 
Then, CLIL research investigated the students' attitudes towards the target language and their progress throughout the course. In addition, it was suggested that the selection of attractive activities adapted to students' proficiency level in combination with ICTs are two key factors that can help students follow a CLIL course.

\section{Music as a Tool in Foreign Language Teaching Programs}

Nowadays, teaching English as a Foreign Language through music and songs seems to be beneficial for the learning process of the target language (Peregoy \& Boyle, 2008; Saricoban \& Metin, 2000; Bartle, 1962; Richards, 1969; Jolly, 1975). This is true in that using music helps English language learners to develop their listening, writing, reading and speaking skills (Peregoy \& Boyle, 2008; Saricoban \& Metin, 2000) as it boosts students' motivation (Bartle, 1962; Richards, 1969; Jolly, 1975).

So far, there seems to be a lack of research in this respect (Salcedo, 2002). For this reason, Schoepp (2001) identified linguistic, affective and cognitive patterns that provided theoretical evidence concerning the effectiveness of songs as a learning tool. Later on, Engh (2013) examined the fields of cognitive science, anthropology, sociolinguistics, psycholinguistics, First Language Acquisition, and Second Language Acquisition, to consider the value of music in the foreign language classroom.

Jane Willis (2013) presented seven activities to work on during music class using a CLIL approach. Thus, students would enjoy activities that involved experimenting with sounds, using music signals or clapping games. Undoubtedly, a wide range of sources would offer students meaningful opportunities to learn music through English. For example, the content pupils would learn in music class consists of creating sound patterns and performing pieces of music. At the same time, they have opportunities to pay attention to the teacher's talk and interact in English as well. Hence, when music is taught in English, it is a content subject that can engage students in the learning process. 
The present research study takes place at a public secondary school located in the Valencian Community in Spain, which offers CLIL programs to students who receive instruction through English in subjects such as history and geography, technology and economics. Two main reasons have triggered the current study: on the one hand, and according to previous research (Khaghaninejad \& Fahandejsaadi, 2016; García, García, \& Yuste, 2012), it seems that learners can benefit from non-linguistic subjects like music due to the use of nonverbal communication; on the other hand, the potential incorporation of a CLIL program in the music classroom as part of the multilingual curriculum of the Spanish educational center has played a decisive role. As a result, a CLIL initiative in music is applied in the English lessons of $1^{\text {st }}$ year secondary education students.

In this line, the current study focuses on the following research question: Did students value positively using English in their music lessons? Hence, the objective of this paper is to investigate to what extent high school students like learning music through English and, on a second instance, to determine the adequacy of music as a subject to be taught in English. By looking into these features, I intend to reflect upon students' feelings about learning music through English and the viability of its future application.

\section{Method}

In this section, the method used to analyze learners' outcomes as well as to collect all the necessary data will be described. To do so, a detailed description of the context, the participants, the tools-including activities, group projects, and a final survey-, the setting of the study, and the lesson plan will be provided.

This music unit, created following a CBI method, has been implemented at a Spanish high school located in the Valencian Community, a region where two co-official languages, Valencian and Spanish are already present in the curriculum. Consequently, the teaching of a foreign language means that all students have to study three languages in their curriculum. 
This educational institution, which offers secondary education, Baccalaureate, and vocational training courses, has been involved in plurilingual experiences and CLIL programs for the past few years (e.g., history and geography, technology and economics). In these CLIL programs, which are characterized by a reduced number of students, the language of communication varied from Spanish to Valencian and English. Teachers use English as the language of instruction most of the time and correct some pronunciation mistakes that are quite usual among learners. However, they switch to students' mother tonguesSpanish or Valencian - when they want students to learn about a tricky concept. Likewise, learners are encouraged to communicate in English, especially when addressing the teacher. These practices are reinforced by the incorporation of some tools like videos, Kahoot and Pixton are employed to complete the activities students are expected to do.

Additionally, other teachers are committed to the instruction of their subjects in English and music is prone to be added to the list. This is the reason why two $1^{\text {st }}$ ESO groups have been selected. These two groups met three times a week in 50-minute sessions during the third semester of the academic year. To carry out this teaching proposal effectively, five sessions were allocated and a final survey was distributed to collect the necessary data for the current study.

\section{Participants}

The subjects in the study were forty-four $1^{\text {st }}$ year high-school students enrolled in English classes. These pupils were part of two different groups, namely those of $1^{\text {st }}$ year Secondary Education A and $1^{\text {st }}$ year Secondary Education B, attending a Spanish public high school. The former group consisted of 14 females and 8 males, whereas the latter group consisted of 8 females and 14 males. These English as a foreign language (EFL) students, with ages ranging from 12 to 14 years old, found themselves in classrooms where the level of English was quite heterogeneous.

However, there were eight students who did not attend high school regularly. Thus, the total number of learners who completed all the 
surveys and activities was limited to thirty-six. With regard to the participants' geographical background, they had Spanish, Arabic, African, Chinese, and Romanian origins (Table 1).

Table 1. Participants

\begin{tabular}{|c|c|c|c|c|c|c|}
\hline \multirow{2}{*}{ Group } & \multicolumn{3}{|c|}{ Students } & \multirow{2}{*}{ Age } & Subject & Level \\
\cline { 2 - 4 } & Male & Female & Total & & \\
\hline A & 8 & 14 & 22 & \multirow{2}{*}{$12-14$} & English & $\begin{array}{c}\text { Secondary } \\
\text { Education }\end{array}$ \\
\hline B & 14 & 8 & 22 & & & \\
\hline
\end{tabular}

Source: Own elaboration.

\section{Tools}

Two different course materials were designed to accomplish the objectives of the present study: initially, ten activities that assessed participants' knowledge of and performance about music genres, and a final questionnaire.

The design of the activities was based on several sources, including webpages, Youtube videos and students' textbooks. For the creation of these activities, the parameters followed were outlined in the Official Spanish Gazette (Royal Decree No. 1105/2014 of 26 December, 2015) as well as in the academic curriculum compiled by the Valencian Government (Decree No. 87/2015 of 5 June, 2016).

As previously mentioned, the data for this research were collected from students' activities, which had been designed to improve learners' communicative skills, particularly those related to oral communication. In so doing, students had to brainstorm music genres, give their own opinion about popular songs in the past, watch videos, and surf on the Internet to find the necessary information for their final presentation, among others.

The final survey was created and passed on to the high-school students to be filled in after the presentation of their final project. It is important to mention at this point that this questionnaire was completely anonymous as it gathered information about the subjects' attitudes towards the incorporation of music through CLIL. This questionnaire is 
employed as a research instrument that involves factual and attitudinal questions (Dörnyei, 2003).

In this final survey, students were asked to answer eleven items that included WH questions, multiple-choice questions and yes/no questions. One of these items was measured in a Likert scale where students had to number from 1 to 5 from "totally agree" to "disagree." The survey, adapted from a previous questionnaire designed by Vaňková (2014), included questions about their personal background and their feelings towards the use of CLIL in music lessons. Some of the questionnaire items were: Q1. Do you like learning foreign languages?; Q4. Have you ever heard of the CLIL approach before?; Q.5 Did you like using English in these music lessons?; and Q11. If you were offered CLIL at high school next year, would you enroll in any subject?

Both groups answered the final questionnaire. When explanations were required, the use of students' mother tongue was not penalized. They were allowed to answer in Spanish as to feel more comfortable explaining how they felt towards this CLIL experience. The design of the questionnaire facilitated the interpretations of the data, which were analyzed quantitatively and qualitatively. Firstly, students were given several response options. Secondly, the qualitative analysis of the questionnaire involved pupils having the opportunity to explain their answers from a subjective point of view. What is more, observation in the classroom setting also provided us with valuable information.

\section{Classroom Setting}

In order to create an interactive environment for the teaching of music in English, all the lessons took place in two ordinary classrooms of the high school allocated to the $1^{\text {st }}$ year Secondary Education groups.

\section{Lesson Plans}

As for the planning and timing of every lesson, the two groups met three times a week in 50-minute sessions during the third semester 
of the academic year. To carry out this study effectively, five sessions dealing with music genres were allocated in April. By means of interactive websites, videos and songs, students could develop their skills in the target language.

This first session was meant to inform students about the existence of different music genres all over the world, to introduce the main features of the most relevant genres and help them to recognize how they sound. In this case, the use of audios taken from YouTube, as well as interactive websites, such as Music-Map (https://www. music-map.com/google.html) and Musicmap (http://www.musicmap. info/) was key.

Reading, written, and speaking activities were the core of the second session. Learners do not only practice their four skills, but they are also taught vocabulary that is essential in the subject of music. First of all, students had to fill in the gaps of a reading that covered Bruno Mars' life. The text, already adapted to the students' level, included specific lexical items that could be useful for their final presentation. After that, students were shown videos of popular songs from the 1960s, 1970s, 1980s, and 1990s. The purpose of this activity was to get to know the students' views, so they were asked to write a short paragraph in which they expressed their feelings briefly. The session was closed with a speaking activity. Pictures of famous artists were portrayed, and they were encouraged to talk about their similarities and their differences.

The third session covered musical instruments. After a brief explanation, participants had to watch a video taken from YouTube and, to make sure that they were paying attention to the video, they were provided with a picture full of instruments. At that point, they were required to tick the instruments that had appeared in the video. In the final activity, employed as a self-assessment tool, learners had to classify the instruments that appeared in the previous video. Finally, the teacher also gave them valuable feedback.

The final project was the core of instruction in the following sessions. Students were grouped heterogeneously, since all the members had different proficiency levels. The purpose of these sessions was to determine whether and how students applied the knowledge acquired in the classroom during the learning process. In groups, students were 
asked to give a presentation on a musical genre that was unfamiliar to them, or a band or artists of a music genre they liked. They were expected to cover several aspects, such as the origins of the genre, famous musicians, some pieces of music and their message, instruments, and the popularity of that genre in different countries. They were given some tips, including a list of webpages in which they could find all the information concerning music genres. The project could be presented in a poster format or in a PowerPoint presentation. At the end of the fifth lesson, a final survey was distributed to the participants to examine their impressions towards the proposal. Both the quantitative results and the analyses of students' comments are discussed in the following section.

\section{Results and Discussion}

In this section, the results obtained in the surveys as well as students' performance on the activities are provided. To begin with, the results from the first lesson are based on both a matching exercise and a final questionnaire that was used as an assessment tool. Then, the results from the second lesson are drawn upon students' written competence in Activity 6. Regarding the third lesson, students' classification of musical instruments is examined. Finally, students' presentations and a final questionnaire are considered.

\section{Activities}

\section{Lesson 1: Activity 3. Match musical pieces with one of the genres in the box}

Results from the third activity, in which students had to match pieces of music with their music genre, suggest that most students could complete the activity successfully. In Group A, approximately $84 \%$ of 
the subjects identified all the music genres correctly, whereas the rest of the participants (16\%) got 4 out of 5 correct answers.

Figure 1 that follows shows similar trends in Group B. Around 89\% of the students in both groups matched each piece of music with its music genre. As can be observed, a reduced number of subjects (11\%) were able to recognize 4 music genres. That being said, it is worth mentioning that students could complete the activity easily.

Figure 1. Results from Activity 3

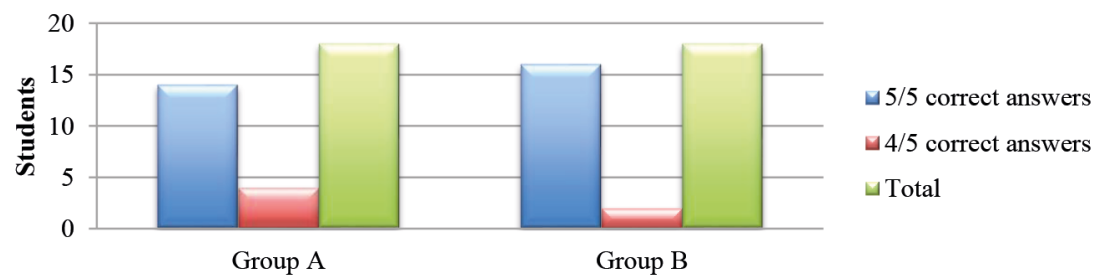

Source: Own elaboration.

\section{Lesson 1: Activity 4. Final test}

Results from the self-assessment test should be pointed out. In this case, Figure 2 illustrates the number of correct answers given by students. Over half of the participants (86\%) passed the questionnaire. Three of them (8\%) seemed to find the activity extremely challenging, as they had serious difficulties in getting the right answers. Clear examples include questions like "Who was the king of rock and roll?," "Which of these music genres is not characterized by complex rhythms?," and "Which artist is not associated with Hip Hop?" (see Appendix 1). Two students (6\%) did not fill in the questionnaire. Their lack of attention during the teachers' explanation, their lack of knowledge, or the difficulty to understand the materials may explain these results.

\section{Lesson 2: Activity 6. Listening of popular songs from the 1960 s onwards}

After playing some popular songs from the 1960s to the 1990s, the teacher asked students some questions, including "Do you think that these songs could be popular today?" Most of the time, they seemed to 
Figure 2. Results of the students' self-assessment test
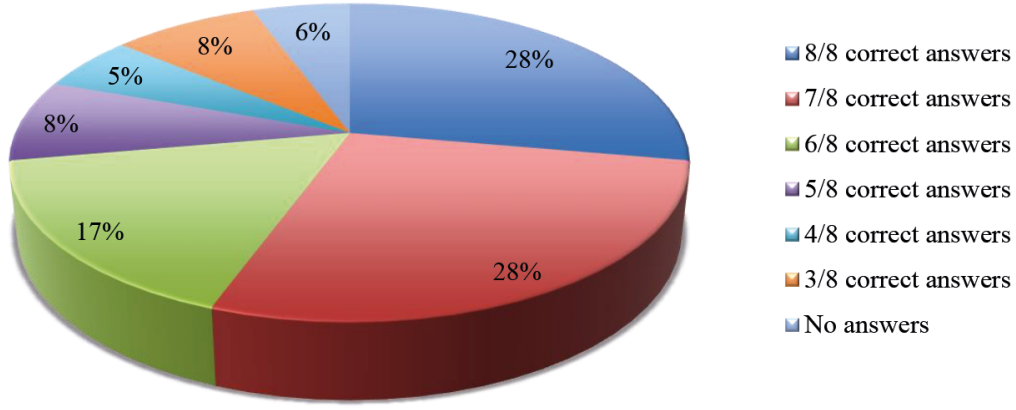

Source: Own elaboration

like the songs and wanted to listen to them for a while. In that sense, they were engaged in the process by saying that they knew some of the songs because they were played on TV ads. Others said that these songs could not be popular nowadays because of the way they sound.

Then, students were asked to write a short paragraph replying to the question "Do you think that popular music is different today?" Participants provided similar answers. Student A said, "In my opinion, music today is different from the past because the rhythm is different." Student B claimed, "Today's music is mostly electronic and we use computers."

\section{Lesson 3: Activity 8. Classification of musical instruments}

Results from the video activity suggest that students had some difficulties in classifying eighteen musical instruments into their corresponding families. String instruments like the guitar, the violin, the viola or the double bass were easy to recognize; however, difficulties arose in the wind and percussion families. Over half of the participants classified the instruments properly. Nevertheless, some students did not realize that the clarinet and the saxophone belong to the woodwind family, whereas the trombone belongs to the brass family. Accordingly, they did not know whether the piano is a percussion or a string instrument. If they did, they would have known that it is a hammered strings instrument. Unexpectedly, three students did not do the activity despite having plenty of time to finish it in class. 
Figure 3 below shows that students' performances in Group B are quite similar. Indeed, the students classified between fourteen and eighteen instruments.

Figure 3. Results from Activity 8 based on the classification of musical instruments

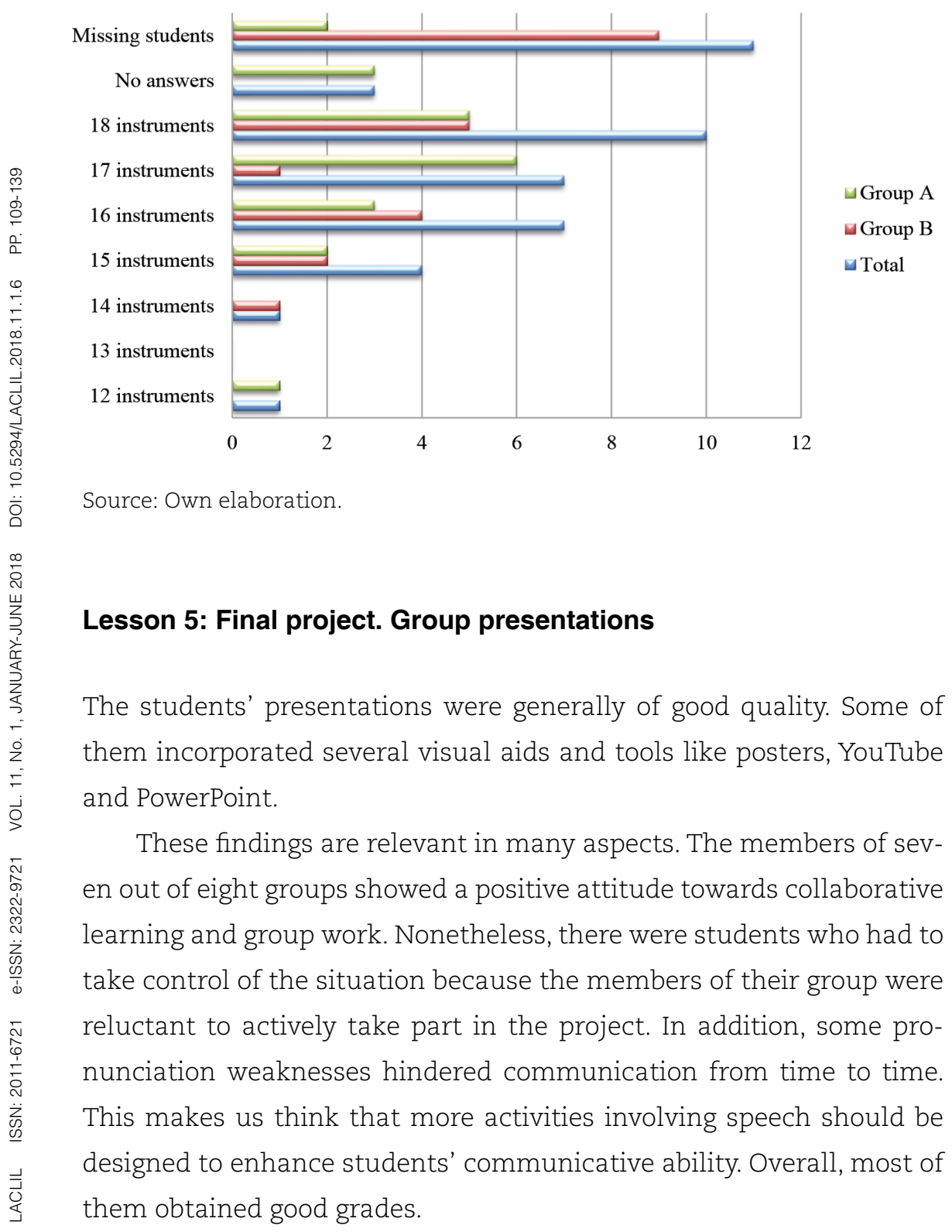




\section{Students' final questionnaire}

At the end of the unit, students were administered a final survey to analyze their thoughts and opinions towards this model based on language and content. The first items were not focused on the CBI model but on the learning of foreign languages (see Figure 4).

Figure 4. Results from the students' final questionnaire

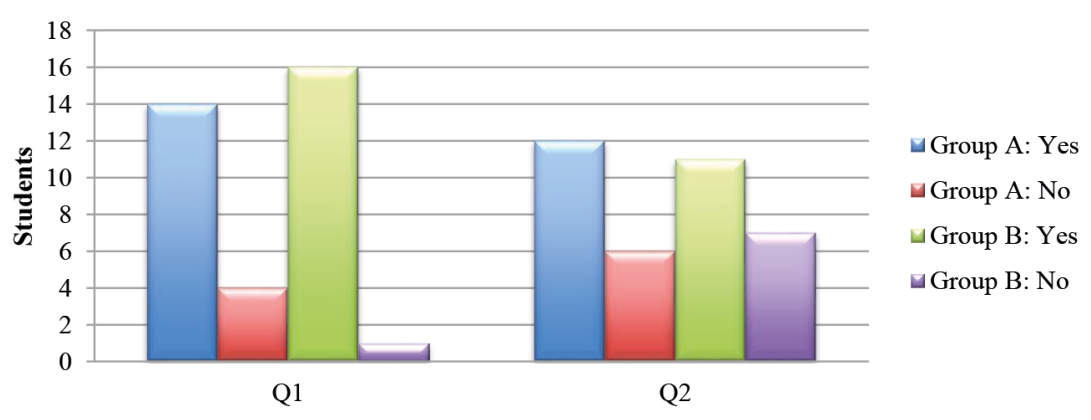

Source: Own elaboration.

As seen above, 31 out 36 students answered in the affirmative to the item Q1: Do you like learning foreign languages? This makes us think that both groups may find the learning of English as a Foreign Language attractive and motivating. Nevertheless, in Q2: Do you think that it is difficult to learn a subject in a foreign language?, the vast majority believe that learning a content subject in a foreign language is a hard process. Actually, students are required to acquire new vocabulary and language skills to communicate and understand new concepts.

The answers for Q3: How long have you been learning a subject through the CLIL approach (using the English language)? determine that, even though most of them did not know CLIL as such, these music lessons were not their first experience with this approach. Thus, a total of 25 subjects claimed having been learning a subject through a foreign language more than once. Notwithstanding this, there are some differences worth mentioning, as Group A's answers are mostly opposed to those of Group B. In this case, few students in Group A knew about the CLIL approach, whereas a large number of students had been learning through the CLIL approach more than once (see Figure 5). 
Figure 5. Results from Q3

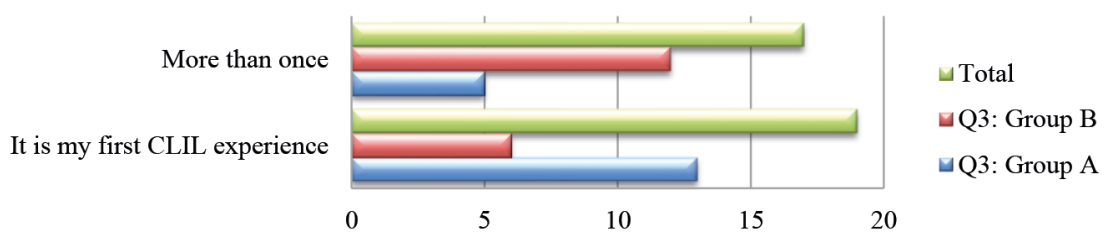

Source: Own elaboration.

In line with this, and as to Q4: Have you ever heard of the CLIL approach before?, those pupils who had heard about this approach pointed out that English was the medium of instruction in content subjects such as music, religion, and arts and crafts in their old schools. Then, these results may be linked to those in Q5: Did you like using English in these music lessons? (see Figure 6). Certainly, 94\% of the subjects reported that they enjoyed using English in these music lessons, whereas only $6 \%$ of the participants did not agree with this statement, which is a key factor to engage them in the learning process.

Figure 6. Results from Q5

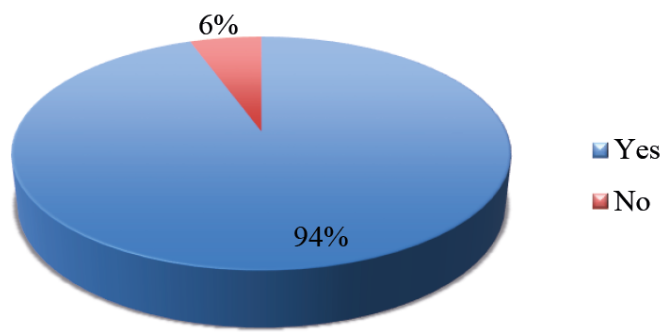

Source: Own elaboration.

As for Q6: Which activities did you like the most?, the favorite activities of the students in Group A seemed to be activities 1 and 6, which are closely followed by activities 2 and 3 (see Figure 7). On the other hand, the most popular activities in Group B include activities 2, 3, 6, and 7, whereas they were not so fond of activities 4 and 9 . There is no doubt that the most appealing activities were those in which online resources were employed. 
Figure 7. Results from Q6

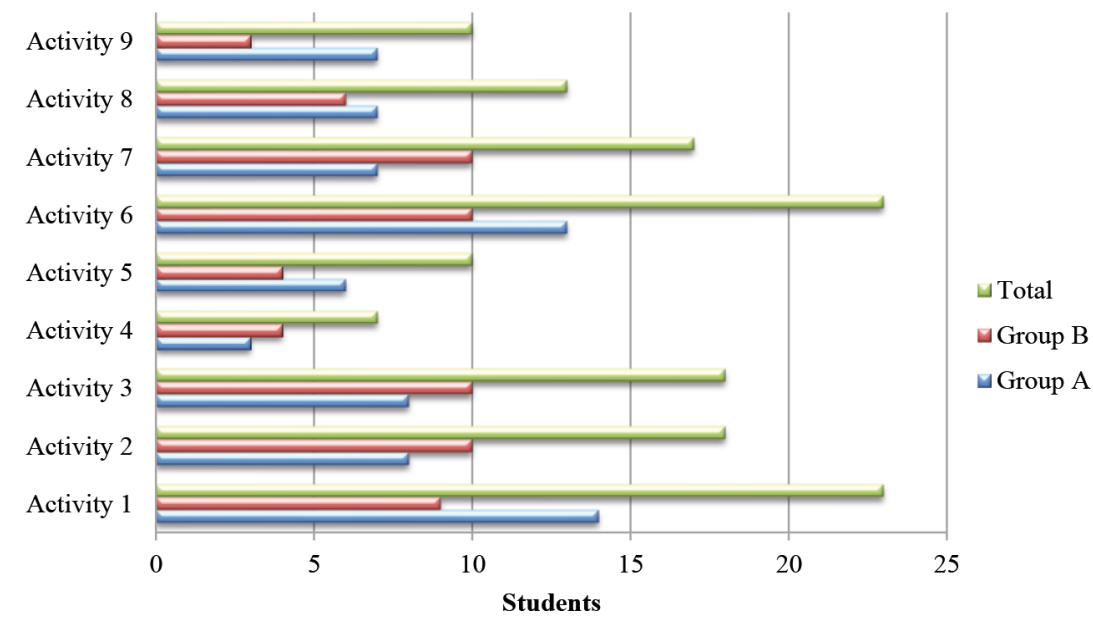

Source: Own elaboration

In Q7, students were asked to choose whether English materials were easy, appropriate, difficult or very difficult (see Figure 8). Generally speaking, all of them seem to be satisfied with the materials as they considered that they were easy or appropriate. Only one student found the materials really demanding, as illustrated in Figure 8.

Figure 8. Results from Q7

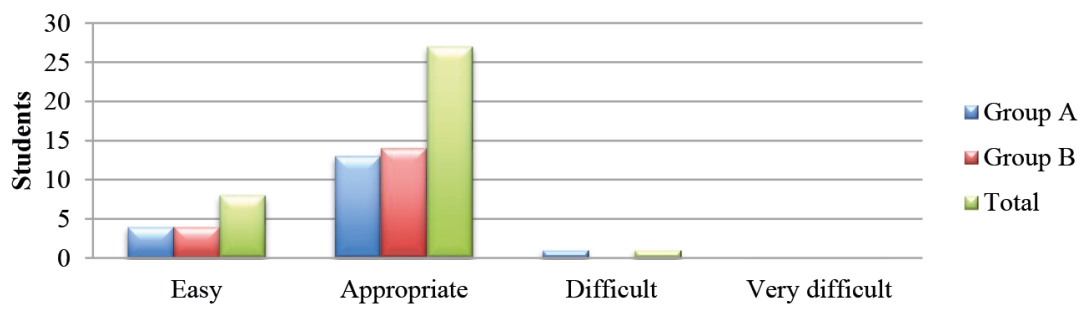

Source: Own elaboration

The results in Q8: These music lessons were more difficult compared to other music lessons are quite remarkable. Clearly, the students' disagreement on this item emphasizes the idea that only two subjects had difficulties in following the lessons, probably because of their proficiency level in the target language. Actually, according to their regular 
teacher, these students had written and oral communication problems due to their poor mastery of the target language. Regarding Q9: Would you rather have a common music lesson?, it is important to highlight differences between both groups. In Group A, eleven participants prefer having these music lessons, in contrast to the rest of their classmates, who prefer learning the content subject in their mother tongue. Unexpectedly, thirteen students in Group B seem to feel more comfortable learning content subjects in Spanish (see Figure 9).

Figure 9. Results from Q8 and Q9

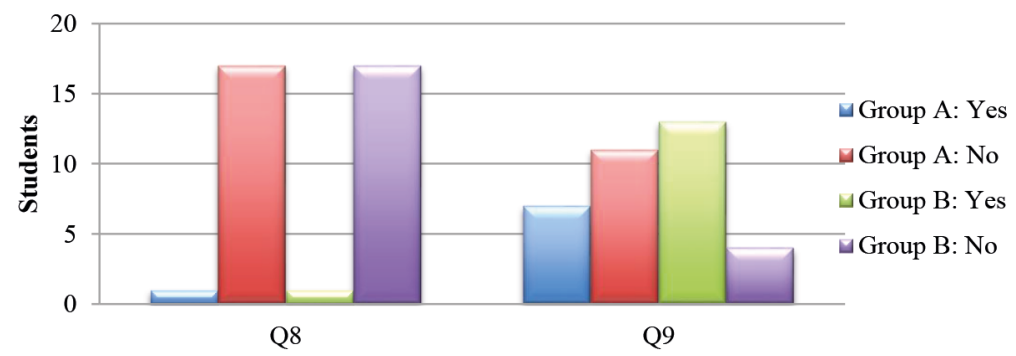

Source: Own elaboration.

As for Q10: What languages have you used when addressing the teacher or your classmates?, most participants acknowledged speaking in Spanish, either when addressing the teacher or their classmates. One of the reasons why this occurs may be because they are afraid of making grammatical or pronunciation mistakes when speaking. Finally, when they were asked Q11: If next year you were offered CLIL at IES Ribalta, would you enroll in any subject?, students in Group A were not sure about being taught in English (see Figure 10). This is the case of ten students who wrote comments like: "I would not enroll any subject because it would be more difficult," "I am not good at English", or "I would not understand what the teacher says." On the other hand, those who were in favor of receiving instruction in English claimed: "We would learn languages other than Spanish," "Apart from learning the contents of a subject I would learn English," and "Because I like the way English sounds."

Group B feels highly motivated to learn content subjects through English. Evidence may be found in those twelve students who stated: "I love English," "It will be useful for my future," "You are exposed to 
the English language constantly," and "I like learning other languages." There were also students who would decide not to enroll a subject that was taught through the CLIL approach for two different reasons: one the one hand, because they are afraid of failing exams; on the other, because they want to be well prepared to face the subject smoothly.

Figure 10. Results from Q11a

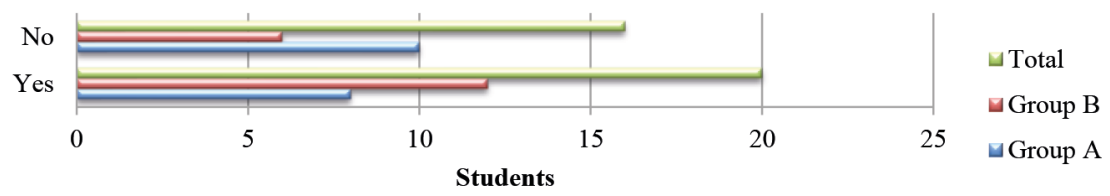

Source: Own elaboration.

The qualitative analyses also revealed that they have a preference for subjects like music (60\%), history (5\%), economics (5\%), arts and crafts (10\%), physical education (10\%), ICTs (5\%) and math (5\%) (see Figure 11). In this case, the predominance of music (60\%) may be influenced by an effective teaching proposal that encouraged pupils to make the most of the learning process. Using materials adapted to their proficiency level was crucial, as students found them appropriate for the activities they were expected to do. Thus, students had the opportunity to put into practice the knowledge acquired through the sessions by playing an active role in the activities and presentations that took place in class.

Figure 11. Results from Q11b

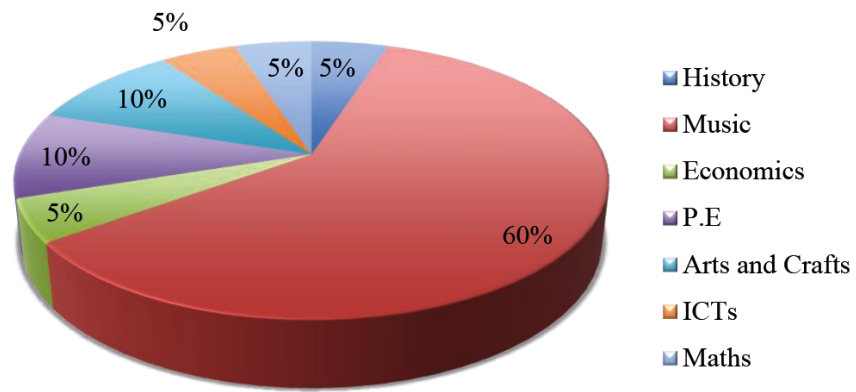

Source: Own elaboration. 


\section{Conclusions}

All in all, the aim of this paper is to investigate to what extent highschool students like learning music through English, and on a second instance, to determine the adequacy of music as a subject to be taught in English.

By looking into these features, conclusions to this study can be drawn in two different dimensions. On the one hand, students' opinions about registering for music as a subject following a CBI approach in the near future, their experience in music lessons and other aspects related to the learning of contents and language have been observed. On the other hand, a small study like the one presented here leads us to think that a deeper analysis is needed to generalize the results obtained.

The present paper departed from the following research question: a) Did students like using English in these music lessons? The results from the final survey suggest that the students in both groups liked using English in these music lessons. Apart from that, over half of the participants would register for subjects taught in English, showing a preference for music lessons.

This study may be relevant to the extent that it shows the beneficial effects of teaching music through English. Learners are eager to participate in class when lessons are presented in a motivating way, particularly when they incorporate audio-visual aids in their lesson routines. Therefore, it can be concluded that music seems to be an adequate subject to be taught in English. However, using English as a medium of instruction in other subjects is still controversial, as some students are concerned about their low English proficiency. In fact, they are not only worried about the degree of difficulty of the materials, but also about examination.

On the one hand, they may not understand the material they are given, which is why the teacher should design and present materials adapted to their level of proficiency. On the other hand, students are worried about passing. The results obtained in the current research 
have demonstrated that, even though the vast majority of the students (94\%) enjoyed using English in class, some of them are afraid of failing exams if they register for a CLIL program. They seem to acknowledge that they will have difficulties in performing activities and passing the subject, but this has not been the case. To overcome these challenges, teachers should make learners understand that they do not need to be scared of failure. Students' command of the target language is not the only element to be examined, given that the CBI approach is also based on the learning of curricular contents. Applying new knowledge should be understood as part of the learning process when following a CBI approach. Hence, exams, projects, daily work and other learning tools should be assessed from a linguistic and a content perspective.

\section{Pedagogical Implications and Further Research}

At this point, the pedagogical implications of a CBI model need to be mentioned. To begin with, this research study also showed the importance of developing learners' autonomy by means of individual activities, as well as promoting collaborative work through a CBI approach.

Secondly, the results of this proposal have proved to be satisfactory. The use of ICTs like YouTube, Music-Map, musicmap.info and Every Noise at Once can contribute to the learning of the subject, since contents and language are combined. In other words, with these online resources learners are exposed to authentic materials, which, in turn, will help them to improve their English skills.

Nonetheless, further research is needed in $1^{\text {st }}$ year Secondary Education groups to validate these results at this educational center. This analysis can be useful overseas, more specifically in Latin American countries, where Spanish co-exists with other languages. Therefore, these results can be meaningful in bilingual or multilingual regions in which language interferences in the foreign language/second language classroom may occur. 


\section{References}

Bartle, G. (1962). Music in the language classroom. Canadian Modern Language Review, Fall, 11-14.

Cenoz, J. (2015). Content-based instruction and content and language integrated learning: The same or different? Language, Culture and Curriculum, 28(1), 8-24. doi: 10.1080/07908318.2014.1000922

Dalton-Puffer, C. (2007). Discourse in Content and Language Integrated Learning (CLIL) classrooms (Vol. 20). Amsterdam, The Netherlands: John Benjamins Publishing.

Decree No. 87/2015 of 5 June on the core curriculum for Compulsory Secondary Education and High School in the Valencian Community. Diari Oficial de la Comunitat Valenciana [2015/5410]. No. 7544. Spain. 10 June 2015. Retrieved from http://www.dogv.gva.es/datos/2015/06/10/pdf/2015_5410.pdf

Dörnyei, Z. (2003). Questionnaires in second language research. Mahwah, NJ: Lawrence Erlbaum Associates.

Engh, D. (2013). Why use music in English language learning? A survey of the literature. English Language Teaching, 6(2), 113-127.

Eurashe. (2018). The Bologna Declaration of 19 June 1999: Joint declaration of the European Ministers of Education. Retrieved from https://www.eurashe. eu/library/bologna_1999_bologna-declaration-pdf/

European Commission. (2015). Language teaching and learning in multilingual classrooms. Retrieved from http://ec.europa.eu/dgs/education_culture/ repository/languages/library/studies/multilingual-classroom_en.pdf

Fortune, T. (2001). Understanding students' oral language use as a mediator of social interaction (Unpublished doctoral dissertation). University of Minnesota, Minneapolis, USA.

Gallardo del Puerto, F., Gómez-Lacabex, E. \& García-Lecumberri, M. L. (2009). Testing the effectiveness of content and language integrated learning in foreign language contexts the assessment of English pronunciation. In Y. Ruiz de Zarobe \& R. M. Jiménez Catalán (Eds.), Content and Language Integrated Learning: Evidence from research in Europe (pp. 63-80). Bristol, UK: Multilingual Matters. 
García, J. V., García, J. J., \& Yuste, J. L. (2012). Educación Física en inglés. Una propuesta para trabajar la higiene postural en Educación Primaria. Retos: Nuevas tendencias en Educación Física, deporte y recreación, 22, 70-75.

Genesee, F., \& Lindholm-Leary, K. (2013). Two case studies of content-based language education. Journal of Immersion and Content-Based Language Education, 1(1), 3-33.

Genesee, F. (2006, December). Myths and misconceptions about early dual language learning. In Symposium presented at the 21st National Training Institute of ZERO TO THREE: National Center for Infants, Toddlers and Families, Orlando, FL.

Heo, Y. (2006). Content-based instruction. TESL Working Paper Series, 4(2), 25-32.

Ioannou-Georgiou, S. (2012). Reviewing the puzzle of CLIL. ELT Journal: English Language Teachers Journal, 66(4), 495-504.

Jäppinen, A. K. (2006). CLIL and future learning. In S. Björklund, K. MårdMiettinen, M. Bergström, \& M. Södergård (Eds.), Exploring dual-focussed education. Integrating language and content for individual and societal needs. Retrieved from http://www.uwasa.fi/materiaali/pdf/isbn_952476-149-1.pdf

Jolly, Y. (1975). The use of songs in teaching foreign languages. The Modern Language Journal, 59(1/2), 11-14. doi: 10.2307/325440

Khaghaninejad, M. S., \& Fahandejsaadi, R. (2016). Music and language learning. Retrieved from https://www.researchgate.net/profile/Mohammad_Khaghaninejad/publication/307014316_Music_and_Language_Learning/links/57c1554008ae2f5eb333f042/Music-and-Language-Learning.pdf

Koller, O., Leucht, M., \& Pant, H. (2012). Effects of bilingual instruction on English achievement in lower secondary schools. Unterrichtswissenschaft, 40, 334-350.

Lasagabaster, D. (2008). Foreign language competence in content and language integrated courses. The Open Applied Linguistics Journal, 1, 31-42.

Lasagabaster, D., \& Ruiz de Zarobe, Y. (2010). CLIL in Spain: Implementation, results and teacher training. Newcastle, UK: Cambridge Scholars Publishing.

Lyster, R. (2007). Learning and teaching languages through content: A counterbalanced approach. Philadelphia, PA: John Benjamins Publishing. 
Marsh, D., Hau, K., \& Kong, S. (2000). Late immersion and language instruction in Hong Kong high schools: Achievement growth in language and non-language subjects. Harvard Educational Review, 70, 302-346.

Nold, G., Hartig, J., Hinz, S., \& Rossa, H. (2008). Klassen mit bilingualem Sachfachunterricht: Englisch als Arbeitssprache [CLIL-classrooms. English as language of communication]. In DESI-Konsortium (Ed.), Unterricht und Kompetenzerwerb in Deutsch und Englisch (pp. 451-457). Weinheim, Germany: Beltz.

Pavón, V., \& Ellison, M. (2013). Examining teacher roles and competences in Content and Language Integrated Learning (CLIL). Linguarum Arena, 4, 65-78.

Peregoy, S. F., \& Boyle, O. F. (2008). Reading, writing, and learning in ESL: A resource book for K-12 teachers (5th ed.). New York, NY: Addison-Wesley.

Richards, J. (1969). Songs in language learning. TESOL Quarterly, 3(2), 161-174.

Royal Decree No. 1105/2014 of 26 December on the core curriculum for Compulsory Secondary Education and High School. Boletín Oficial del Estado No. 3. Spain. 3 January 2015. Retrieved from https:// www.boe.es/boe/dias/2015/01/03/pdfs/BOE-A-2015-37.pdf

Ruiz de Zarobe, Y., Sierra, J. M., \& Gallardo del Puerto, F. (2011). Content and Foreign Language Integrated Learning: Contributions to multilingualism in European contexts. Bern, Switzerland: Peter Lang.

Salcedo, C. S. (2002). The effects of songs in the foreign language classroom on text recall and involuntary mental rehearsal (Doctoral dissertation). Southeastern Louisiana University, USA. Retrieved from https://digitalcommons.lsu.edu/gradschool_dissertations/1458

Saricoban, A., \& Metin, E. (2000). Songs, verse and games for teaching grammar. The Internet TESL Journal, 6(10), 1-7. Retrieved from http:// iteslj.org/Techniques/Saricoban-Songs.html

Schoepp, K. (2001). Reasons for using songs in the ESL/EFL classroom. The Internet TESL Journal, 7(2), 1-4. Retrieved from http://iteslj.org/Articles/Schoepp-Songs.html

Stoller, F. L. (2008). Content-based instruction. In N. Van Deusen-Scholl \& N. H. Hornberger (Eds.), Encyclopedia of language and education. Vol. 4: Second and foreign language education (pp. 59-70). New York, NY: Springer.

Vaňková, Š. (2014). CLIL in music education (Doctoral dissertation). Masarykova univerzita, Pedagogická fakulta, Czech Republic. 
Willis, J. (2013). English through music: Designing CLIL materials for young learners. Padres y Maestros, 349, 29-32.

Wolff, D. (2002). On the importance of CLIL in the context of the debate on plurilingual education in the European Union. In D. Marsh (Ed.), CLIL/EMILE. The European dimension. Actions, trends, and foresight paten-

134 til (pp. 47-48). Jyväskylä: University of Jyväskylä.

Yip, D., Twang, W., \& Cheung, S. (2003). Evaluation of the effects of medium of instruction on the science learning of Hong Kong secondary students: Performance on the science achievement test. Bilingual Research Journal, 27(2), 295-331.

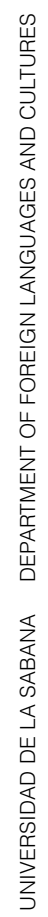




\section{Appendix}

\section{LESSON 1}

1. In groups discuss about the following questions:
a. What kind of music do you like?
b. Who are your favorite singers?
c. What kind of music do they play?
d. Is there any kind of music that you can't stand?

2. Brainstorm different musical genres:
a. How many genres are you familiar with?
b. Which have you never heard of?

3. Now we are going to listen to several pieces of music. Match each piece with one the genres in the box.

country, R\&B, hip hop, jazz, rap, reggaeton, reggae, pop, rock, indie, classical music

SONG 1

SONG 2

SONG 3

SONG 4

SONG 5

4. Answer these questions:

1. In classical music there are instruments like...
a. the piano, the organ and the harpsichord
b. the drums, the flute and the metals
c. the cello, the keyboard and the bass

2. Which of these instruments are played in jazz?
a. guitar, violin and piano
b. saxophone, trumpet and violin
c. trumpet, trombone and guitar 
3. Who was the king of rock and roll?
a. Michael Jackson
b. Adam Levine
c. Elvis Presley

4. Which of these music genres is not characterised by complex rhythms?
a. Reggae
b. Pop
c. Jazz

5. Into which music category would you place Chopin?
a. contemporary
b. classical
c. country

6. Which artist is not associated with Hip Hop?
a. Andrea Bocelli
b. Wiz Khalifa
c. The Weeknd

7. Which musician is key in the development of jazz?
a. Benny Goodman
b. Johnny Mathis
c. Louis Armstrong

8. What are country songs about?
a. Everyday life
b. Hate
c. Holidays 


\section{LESSON 2}

\section{Complete the text with the words in the box ${ }^{1}$ :}

songwriter, guitar, vocalist, bass, pop, rapper, album, percussionist, single, drummer, musician

Bruno Mars was born Peter Gene Hernandez on October 8, 1985, in Honolulu, Hawaii. He was the son of Pete ("Dr. Doo-Wop") Hernandez, a Latin Hernandez, a Filipina His uncle is an incredible and Bernadette brother is a great As a young teenager, he taught himself to play piano, guitar, __ and percussion. After graduating from high school, he moved to Los Angeles, California, to pursue a career as a About that time he took the stage name Bruno Mars. He is now a famous __ star, music producer and award winning singer-

B.o.B, and Billionaire by He co-wrote songs such as Nothin' on You by hip-hop artist Travie McCoy.

His Unorthodox Jukebox, which included the hit songs Locked out of Heaven, When I Was Your Man and Treasure, won the Grammy for best pop vocal album. Then, the Uptown Funk, which recalled 1980s funk and R\&B, won the Grammy for record of the year.

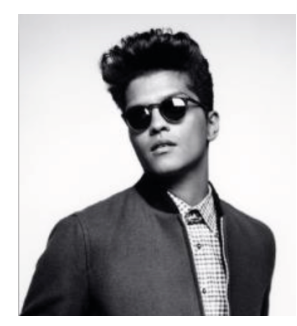

6. Popular songs from the 1960s, 1970s, 1980s, and 1990s.

» What do you think about the titles of the songs? Are they silly? What is most striking about them?

» Do you think these songs could be popular today?

» Do you think that popular music is different today? Write a short paragraph giving your opinion.

7. Work in groups. Look at the pictures. Do you know who they are? Talk to a partner about what they all have in common, and the differences among them. Write your answers.

1 Adapted from http://kids.britannica.com/comptons/article-9625494/Bruno-Mars 

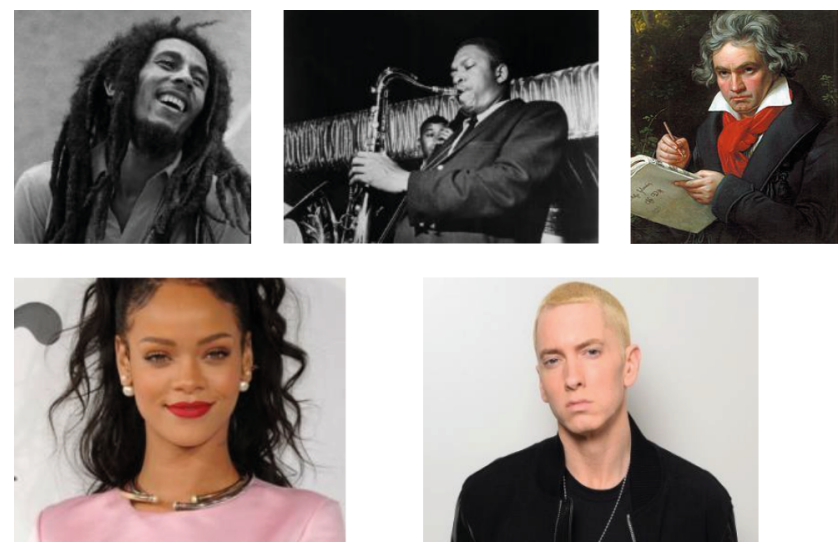

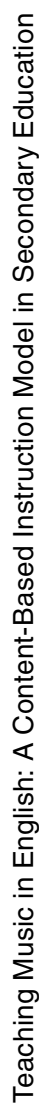

\section{LESSON 3}

8. Which of these instruments have appeared in the video? Tick them.

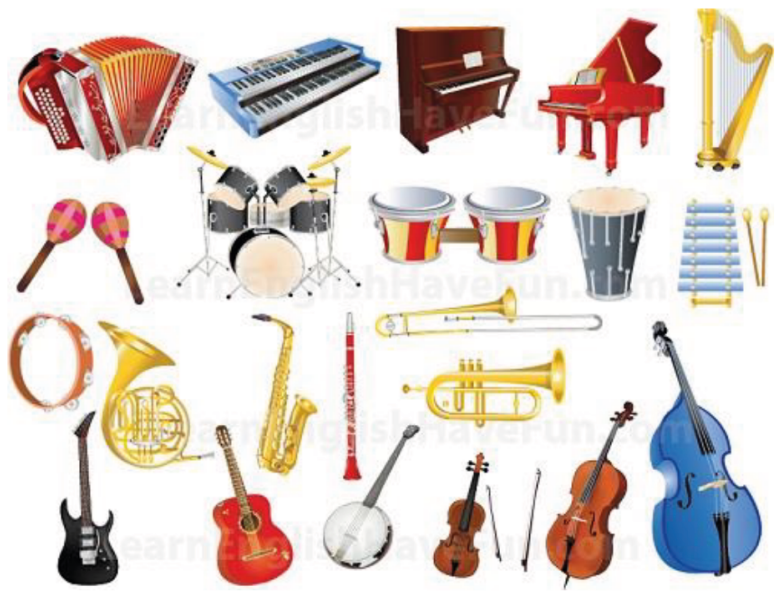


Evaluation. Classify these instruments in the table below.

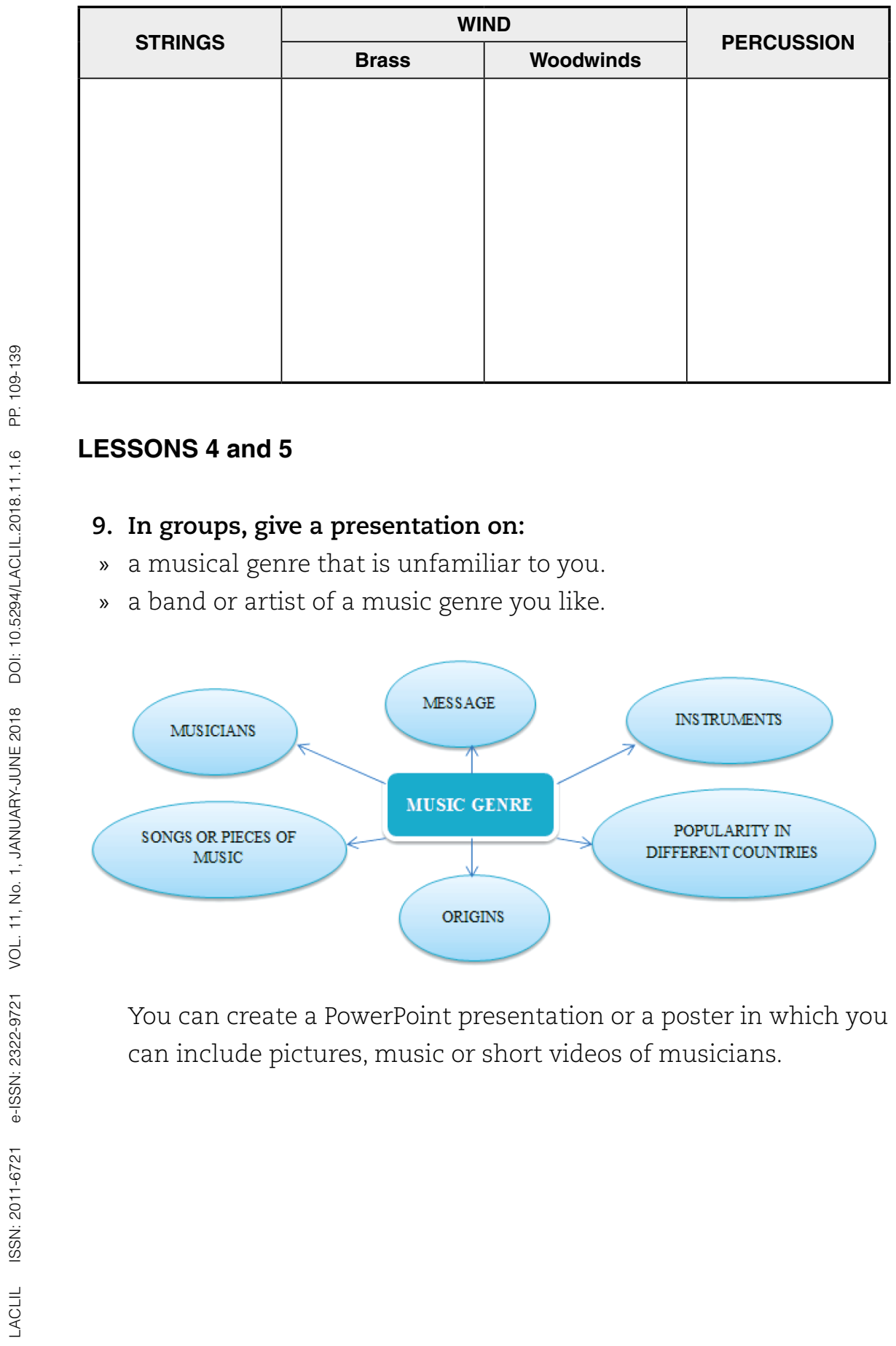


